\title{
A Dutch Christian Communicator, Desiderius Erasmus Roterodamus
}

\section{Yerodin L. Carrington}

Regent University, Virginia

\begin{abstract}
This is a short paper exhibiting the Christian Communication contributor of a historical well-known figure. Desiderius Erasmus Roterodamus was a notable Christian scholar, teacher, preacher and philosopher that reigned during the Northern Renaissance. The influence upon this research study was due to a popular, huge, zone high school located in Flatbush, Brooklyn at the intersections, of Flatbush and Church Avenues. Erasmus Hall Educational Campus comprise five Gothic-style high schools founded in 1786 by the Flatbush Dutch Reformed Church.
\end{abstract}

Keywords—Erasmus, Dutch, Northern Renaissance, Christianity, Philosopher, Humanist, Theologian.

\section{INTRODUCTION}

Desiderius Erasmus Roterodamus was a Dutch Philosopher and Christian Humanist that scholarly studied and translated a lot of work during the Northern Renaissance. The Northern Renaissance was a 300-year golden age of enlightenment, which was known during the 15 th century, as an artistic movement. This Renaissance was a European artistic movement occurring north of the Alps, where they were involved with the use of oil painting, from the Italian Renaissance.

As a Christian Humanist, Desiderius Erasmus worked as a scholarly theologian that translated biblical scriptures, and added content to the New Testament in Greek. This doctrine was published in 1516 during the Renaissance movement, along with the combination of Christian faith, and a strong interest in the nature of humanity. The New Testament was created to redeem humanity with principles of human dignity, individual freedom, and happiness teachings to one another. "The fluidity of religious identities in the early years of the Reformation stemmed in part from the complex and ambiguous relationship between humanism and reform, which almost always featured a shared enthusiasm for biblical revival." (Wooding, L., 2017) It is the philosophy of Jesus Christ, where God is most satisfied, and when humans are glorified.

However, Desiderius Erasmus Roterodamus was the first and most famous Dutch Philosopher known to mankind.
Desiderius Erasmus studied, and shared the proper human behavior in order to live, a good long life from a Dutchman's perspective. Erasmus urge for wisdom led to his studies of mankind, through the Bible, ancient literature, and fine arts to gain a better understanding of social and moral values of a Christian. In addition, Erasmus was a translator that taught humanism by deciphering some of the most controversial, early Renaissance figures that influenced their society. "Using his humanist touch, he penned several editions of the New Testament in Latin and Greek, which in turn led to the Protestant Reformation and Catholic-Counter Reformation." (Who was Desiderius Erasmus?) These translations of the Bible, along with his knowledge of Christ, lead believers to follow, and convert to Christianity.

The Life of Desiderius Erasmus Roterodamus

Desiderius was born, Gerrit Gerritszoon, and estimated to be birthed on October 28, 1466 in Rotterdam, Burgundian Netherlands (Holland) Holy Empire. Desiderius Erasmus Roterdamus was birth in wedlock, between the union of Roger Gerald and Margaret Rogerius, where Gerrit Gerritszoon is the indication of Gerald Geraldson in Dutch. Gerald Geraldson was christened the named "Erasmus" meaning "beloved" after Saint Erasmus of Formia, who Roger Gerald personally favored, while Desiderius meant "desired one". Saint Erasmus of Formia had great respect as a patron of sailors and expert in pain relief of the abdominal, during the Eastern Roman Emperor Diocletian in the third 
century. Roger Gerald was a curate and Catholic Priest in Gouda, while Margaret Rogerius was the daughter of a physician from Zevenbergen, who became a monk. There is very little information known about Erasmus' mother, but she was believed to be a housekeeper of Roger. However, Erasmus lived in Rotterdam for four years, and eventually moved to Gouda with his older brother Peter, where he started school at age 4. At age 9, Erasmus along with Peter were sent to a prestigious Latin grammar school in Deventer, owned and operated by the charter clergy of the Lebuinuskerk (St. Lebuin's Church). "He advanced as far as the third-highest class at the chapter school of St. Lebuin in Deventer. One of his teachers, Jan Synthen, was a humanist, as was the headmaster, Alexander Hegius. The schoolboy Erasmus was clever enough to write classical Latin verse that impresses a modern reader as cosmopolitan." (Tracy, J. D., n.d.) Erasmus and Peter were in the care of their parents until the plague of 1483, which took them away from Erasmus and this world. The Plague, also known as The Great Plague, Black Plague or Black Death, was an epidemic of the Yersinia pestis disease that claimed the lives of 75 to 200 million humans in Eurasia. "Yet some twenty five years later, there is still relatively little scholarly discussion of plague outbreaks after 1348 or of the cumulative psychological effect of recurring epidemics." (Marshall, L., 1994) This plague peaked in Europe between 1347 and 1351 with several outbreaks, which led to a second, and third term of the plague's pandemic. The Great Plague killed 30\% to 60\% of Europe's population, and consequently, it took 200 years for the world's population to recover.

After the deaths of Roger Gerald and Margaret Rogeris, Erasmus and Peter lived with their appointed guardians for two years before being sent to Monastery School of Hertogenbosch, to become monks. Their education was provided by the Brethren of the Common Life, who fostered monastic vocations. The loss of Erasmus' parents and the mistreatment of his guardians, forced Desiderius Erasmus into priesthood, to avoid poverty with a strong educational background in monastery. Erasmus entered a consecrated lifestyle in St. Augustine, located in Stein, South Holland, where he studied pure classical usage and manifesto. Desiderus paraphrased Lorenzo Valla's Elegantiae, which led to the outrage of some "barbarians" that disliked his work; however, Erasmus' monastic superiors became barbaric to defend him from those of discouragement during his studies. In April 1492, Desiderius Erasmus was ordained into priesthood and accepted a trip to Italy, as the
Latin Secretary to Henry of Bergen. At the age of 25, Erasmus then assisted the Bishop of Cambrai, who was impressed with his skill of writing letters in Latin to work in Italy. Bishop Henry then invited Erasmus to travel to Paris, France to study classical literature, along with the Latin culture aboard. During this business trip to Paris, Erasmus was able to introduce the Renaissance Humanism culture to Western Europe with respect to the ascetic Jan Standonck.

Over the following 10 years, Erasmus traveled between France, the Netherlands, and England, as one of the world's most notable Christian scholar lecturers. He produced some of his best writings while studying at the University of Paris in the College de Montaigu. Erasmas became the Chief in the Institution of Scholasticism, where his influence transitioned the organization into the School of Renaissance Humanism. As a lecturer, Erasmus worked with Henry while attending school in Paris, where he began reading Origen and Saint Paul to digest the teachings of moral concerns from Christ in Greek. These works influenced the 1503 publishing, Enchiridion militis Christiani (Handbook of a Christian Knight), where Erasmus gave readers the spiritual interpretation of the meditated scriptures along with the teachings of Christ. Desiderius Erasmus continued to study the Greek language knowing he would gain a deep understanding of theology through his research. Desiderius then discovered the manuscript of Valla's Adnotationes on the Greek New Testament that he published in 1505, and sought more information to support his findings. Erasmus then sailed to England in search for references on the Greek New Testament, but landed the perfect opportunity in the promiseland of Northern Humanism - Italy, as the new tutor for the family of Henry VII. Desiderius Erasmus spent the rest of his life in Italy, after becoming the Doctor of Divinity at Turin University. He then polished his knowledge of Greek literature, and became an English Professor of Divinity for Lady Margaret at the University of Cambridge. Although it was well-known that Desiderius Erasmus Roterodamus hated English wine and their local weather, he stayed on-campus in Queens College - Cambridge between the years of 1510 and 1515 occupying rooms located along the "I" staircase. In 1516, the Greek translation of the New Testament, Novum Instrumentum omne, was published from Latin Vulgate by Erasmus. After Martin Luther's Ninety-five Theses was published in 1517, the Protestant Reformation erupted as Erasmus attended debates regarding human nature, free will, and religion. He followed-up by expressing his views against 
Martin Luther in his 1523 publishing, De libero arbitrio, before he became ill. Desiderius suffered from poor health and complained about Queens College's harsh wine supply, as it was the primary remedy for gallstone in the Renaissance Era. On July 12, 1536, Desiderius Erasmus Roterodamus fell ill and died of a dysentery attack, during his move back to the Netherlands. With all respect to Christ, Desiderius Erasmus Roterodamus didn't receive his last rites as a priest, although Erasmus exhibited a direct relationship with God to his believers.

Desiderius Erasmus Roterodamus was an excellent preacher, scholar, and theologian of the Northern Renaissance, where he made a difference in mankind. Erasmus served as an editor translating works from Latin to Greek by St. Jerome, St. Hilary and St. Augustine during his studies. Desiderius wrote about the legendary freedom fighter and rebel Pier Gerlofs Donia, who was known for his enormous size and strength, through his journey to become a Doctor of Divinity. Pier Gerlofs Sonia, also known as Grutte Pier, or Big Pier, was a Frisian rebel leader and pirate that led the Frisian Rebellion from 1515 to 1519 against a very violent military force called The Black Band. Erasmus also padded biographies on Irenaeus, Origen, and Chrysostom due to their contributions to Christianity. Below, I highlighted a few attributes of Christian contributions that Desiderius Erasmus Roterodamus embarked upon.

- Irenaeus was a Greek Bishop of Lugdunum (Lyons, France) known for guiding and expanding Christian communities throughout Lugdunum. Irenaeus was taught theology by Bishop Polycarp, who became a disciple of the Apostle John, and saved Christians from an authorized mass slaughtering in Lyons by Marcus Aurelius. He wrote various works on myths and the structure of Valentians' Gnosticism, including the creator God, supreme God, and other Gods in the world.

- Origen, real name Oregenes Adamantius - also known as Origen of Alexandria, was a known early Christian theologian and scholar of the early Greek Church. Origen lived in Alexandria, Egypt in the first century working as a grammar teacher to support his mother, and six younger brothers, due to his father's martyrdom for execution. Oregenes Adamantius wrote over 200 treatises on various topics regarding theology with his most notable work being Hexapla. Hexapla was Origen's synopsis of the six versions of the Bible's Old Testament.
"Origen's purpose in the Hexapla was merely by the aid of 'the Hebrew and of the later translations which squared with it to demonstrate the unsatisfactory character of the current text of the church Bible, and the object was accomplished by leaving well enough alone, the parallel arrangement in columns sufficing to bring out its incongruities from the point of view of the Hebrew, which was the standard and the truth." (Margolis, M. L., 1916)

- Chrysostom, also known as Saint John Chrysostom, was a Doctor of the Roman Catholic Antioch Church, who denounced the abuse of authority. He was a well-known preacher and public speaker born in the Antioch of Syria, in 349. Chrysostom was known as the greatest preacher ever heard in the Christian Pulpit, where he earned the name Chrysostom for golden-mouthed (in Greek). Saint John Chrysostom was also considered one of the greatest leaders in the Greek Church. He was honored as a Saint in the Oriental Orthodox, Eastern Orthodox, Catholic, Anglican, and Lutheran churches due to his involvement within Christianity. Chrysostom was then appointed Archbishop of Constantinople from being a deacon in Saint Meletius of Antioch.

Desiderius Erasmus Roterodamus was a great scholar that managed to communicate and express his views of Christianity through literature. He influenced the masses to follow Christianity by teaching the history of Christ, the Apostles, and heroes of Christianity. Although he wrote about various topics, here are some notable works of Desiderius Erasmus' publishings that contributed to Roman Catholic Church and its biblical truths.

- Manual of the Christian Knight (also known as, the Handbook of the Christian Soldier or Enchiridion Militis Christiani) (1503) was compromised during a trip to France with Bishop Henry. As followers witnessed, Erasmus was told by Jean Viorier that monastery life was pointless and silly. This debate with the very fiercest preacher, Viorier, influenced the writing of a Handbook for Christian Knights in 1501 by Erasmus. The lost of Viorier's discipline who faced death in a calm, peaceful manner trusting in God without characterizing deep sincerity triggered this work. At a later meeting, Jean Viorier lent Erasmus the works of Oregenes Adamantius for future 
reference. Oregenes was an early Greek theologian and biblical scholar, who pronounced the promotions of moral and spiritual order through pictures and poems embedded in a storyline. This methodology led to the crafting of the 1516 publishing, Institutio principis Christiani (Education of a Christian Prince). The Manual of the Christian Knight provides a vivid explanation of approaching the modern attitude and philosophy of the second century. It exhibited the basic sermons regarding the written law of Christ for Christians to follow their path of righteous. This small book was translated into vernacular languages to influence the atheists, independent intellectual thinkers, and the anti-Christians of moral and social powers of life.

- The Praise of Folly (written in 1509, published in 1511) "was written for Sir Thomas More with whom Erasmus had made friends on his trip to England. It is a spoof, in which Folly demands praise for all of the ways of the world. It is under Folly's influence that people behave as they do and that institutions are organized with an upside-down logic. Erasmus was particularly scathing in his description of the state of religion and of the Catholic Church. Historians are fond of saying that Erasmus laid the egg that Luther hatched." (Erasmus, D., n. d.)

- Sileni Alcibiadis (1515) is the most direct essay assessed in regards to church reform of the Northern Renaissance. Erasmus criticized the Priests and people in power of abusing their wealth and dictating the poor as servants. He also believed the Priest should be pure, but sprayed away without being condemned. This work suggests the upper class should be important and guide those in need. Erasmus believed the Roman Catholic Church's purpose to assist those in living a pure Christian life, according to the Gospel.

- Institutio principis Christiani (Education of a Christian Prince) (1516) was Erasmus' written advice on the characteristics of the "Good Christian Prince" dedicated to a young king Charles of Spain, who later became the Habsburg Emperor Charles V. "It was written at around the same time as Machiavelli's famous work The Prince (written 1513, published 1532), but provides very different advice. Instead of advocating ruthlessness and cruelty as effective governing techniques, Erasmus recommends education, humility, and policies of peace." (Desiderius Erasmus' Institutio Principis Christiani, 1516, 2017, March 3). The Education of a Christian Prince (1516) was published three years after Niccolo Machiavelli's The Prince was written; it served as a document to show love to Prince Charles rather than filling him with fear. The Education of a Christian Prince also described The Prince as a modest warm hearted individual with great energy.

- Spongia adversus aspergines Hutteni (The Sponge of Erasmus against the Aspersions of Hutten) (1523) is a 12-page pamphlet where Erasmus exhibits his skills in semantics to answer a misinterpretation to Ulrich von Hutten (a German Protestant scholar who followed Martin Luther). Martin Luther accused the Roman Catholic Church of corruption and called Erasmus a coward for not addressing the issue accordingly. This led to a mature expression of moral concerns and freedom of will for mankind written in Latin, because it was the primary language at that time.

- Ciceronianus (1528) is a treatise criticizing the Latin style of writing during the early 16th century which attempted to imitate the works of Roman Philosopher, Marcus Tullius Cicero. Pigman, G. W. (1980) explained, Ciceronianus believed "treatises on imitation are a logical place to look for discussions of the relationship of past to present because they are concerned with using the writings of the ancients as models for contemporary composition. And since they are usually concerned with the stylistic possibilities of Latin, they almost always have to confront an inescapable fact of historical difference." It discussed the significance of education, interest of a student, and methods of teaching through the translations of holy text, which some were in a symbol system.

- Ecclesiastes (Gospel Preacher) (1536) was Erasmus' latest major publishing before his death that consist of four sections. They are composed in metaphorical interpretation of effective preaching and the attributes of a Christian Educator. A theological treatise, an outline textbook on hermeneutics, and a list of sermon developed topics were made clear in Erasmus' written product on the 
art of preaching. Ecclesiastes discussed the values of the office of the priest, rhetorical devices that influence a preacher's repertoire, and the subjective worth of sermons and scriptural references.

\section{CONCLUSION}

Desiderius Erasmus Roterodamus was a very attentive and knowledgeable individual that reigned during the late 1400s, early 1500s. He lived to be 69 years of age, while residing and traveling throughout Europe. Erasmus studied monetary and theology throughout his life, as he progressed to be a Doctor of Divinity. He studied Greek theology to practice and share the proper moral concerns of God from ancient history. Ong, W. J. (2002) clarified that scholars of the Middle Age and Erasmus Age simply translated early documents of Greek literature, from oral traditions of illiterate societies to literate cultures. Erasmus specialized in translating Greek literature with a strong following of believers during the Northern Renaissance period. Desiderius Erasmus Roterodamus wrote countless works, but only a few were published with other works expressed during his public speeches and debates. He was a Catholic and Protestant Humanist that pronounced human rights and free will through his position in the Roman Catholic Church. Erasmus also argued and defended the Bible in Novum instrumentum during the incline of the Protestant Renaissance. After Erasmus' ideas and works were stolen during the Protestant inclination, it seemed like the Roman Catholic Church were competing when evangelizing during masses. "Catholics throughout Europe would feel, in hindsight, that the writings of Erasmus had spurred Luther on, or, as they put it, that Erasmus had laid the egg which Luther hatched. For years they would be hell-bent on demonstrating that the humanist was in large part responsible for the outbreak of the Lutheran heresy." (Wegman, R. C., 2011)

Desiderius Erasmus Roterodamus was a very witty and brilliant individual that transcribed certain literatures that were orally spoken in Greek or English into Latin, so it could not be revised. Gilman, W. E. (2003) clarified, "De copia had more than 150 'editions' before the end of the sixteenth century, the translators had many difficult textual problems to resolve." He also invented Latin words within his native tongue to gain the support of those that need the message given, or assistance with conveying the same message. Desiderius Erasmus Roterodamus had a tremendous influence upon the Northern Renaissance of Europe, where he expressed his views upon the Roman Catholic Church to correct their actions. Erasmus was consistent with his biblical studies, which influenced Protestant believers when their movement emerged. Most importantly, anyone can learn how to live a good successful life with moral and social concerns through Desiderius Erasmus Roterodamus' works. Blessings.

\section{REFERENCES}

[1] Erasmus, D. (n.d.). In Praise of Folly (1509 C.E.). Desiderius Erasmus: In Praise of Folly, 353-356. Retrieved from https://www.olma.org/ourpages/auto/2014/9/4/51647061/eras mus reading.pdf

[2] Desiderius Erasmus' Institutio Principis Christiani, or The Education of A Christian Prince 1516. (2017, March 3). Retrieved October 5, 2019, from https://www.bl.uk/collection-items/desiderius-erasmusinstitutio-principis-christiani-or-the-education-of-a-christianprince-1516.

[3] Gilman, W. E. (2003). New Books. EBSCO Publishing.

[4] Margolis, M. L. (1916). Hexapla and Hexaplaric. The American Journal of Semitic Languages and Literatures, 32(2), 126-140. doi: 10.1086/369791

[5] Marshall, L. (1994). Manipulating the Sacred: Image and Plague in Renaissance Italy*. Renaissance Quarterly, 47(3), 485-532. doi: 10.2307/2863019

[6] Ong, W. J. (2002). Orality and literacy: the technologizing of the word (3rd ed.). London: Routledge.

[7] Pigman, G. W. (1980). Imitation and the Renaissance sense of the past: The reception of Erasmus' Ciceronianus. The Journal of Medieval and Renaissance Studies, 1-46.

[8] Smoluk, M. (2007). Lublin Studies in Modern Languages and Literature. Royal Education in the Tudor Age, 31, 194-210.

[9] Tracy, J. D. (n.d.). Erasmus. Retrieved October 4, 2019, from https://www.britannica.com/biography/Erasmus-Dutchhumanist.

[10] Wegman, R. C. (2011). Obrecht and Erasmus. Journal of the Alamire Foundation, 3(1), 109- 123. doi: 10.1484/j.jaf.1.102195

[11] Wooding, L. (2017). Erasmus and the Politics of Translation in Tudor England. Studies in Church History, 53, 132-145. doi: $10.1017 /$ stc.2016.9 